\title{
Netiquette concept at the assessment of college student social competence with TOPSIS method
}

\author{
Rianto $^{1}$, Sri Mulyani ${ }^{2, *}$ \\ ${ }^{1}$ Department of Informatics, Universitas PGRI Yogyakarta, Daerah Istimewa Yogyakarta, Indonesia \\ ${ }^{2}$ Aerospace Engineering, Adisutjipto Institute of Aerospace Technology, Daerah Istimewa Yogyakarta, Indonesia
}

\begin{tabular}{l}
\hline \hline Article Info \\
\hline Article history: \\
Received November 10,2021 \\
Accepted November 24, 2021 \\
Published November 30,2021 \\
\hline
\end{tabular}

Keywords:

netiquette

topsis

social competence

\begin{abstract}
Social competence for college students is important during the process of implementing the practicum. From social competence, we can find out the students' capable in several ways such as the ability to collaborate, s peak in forums, reduce social conflicts in the environment, make a network and much more. In this study, it provides a solution model for assessing social competence in college students when carrying out practicum. The purpose of the study was to develop an assessment model by measuring students' social competence during the implementation of the practicum. The number of correspondents in the study was 78 students taken from the number of practicum students in Aerospace Engineering study program. The data analysis technique uses the TOPSIS method, where the results of this study will obtain the best rank of 78 practicum students who have the highest social competence value. The model of the assessment can be used by lectu rers in Aerospace Engineering study program, Adisutjipto Institute of Aerospace Technology during the practicum process or after it. By having this assessment model, the advantages got for Adisutjipto Institute of Aeros pace Technology is the campus can synergize in creating graduates with a global and humanistic character.
\end{abstract}

\section{Corresponding Author:}

Sri Mulyani,

Aerospace Engineering,

Adisutjipto Institute of Aerospace Technology,

Jl. Janti, Blok-R, Lanud Adisutjipto Yogyakarta, Daerah Istimewa Yogyakarta, Indonesia.

Email: "srimulyani042@gmail.com

\section{INTRODUCTION}

The beginning of 2020 was the beginning of a difficult year, it was due to the Covid-19 viru s that entered Ind onesia. First time, the case of covid appeared in Chin a and wa s la ter referred to a s the coronavirus disease COVID-19 [1]. There are many bad effects caused by this virus, on e of them is ed ucation field . COVID-19 virus has greatly impacted most of the students' life outside the cla ssroom[2], many students have to study a thome during the COVID-19 pandemic[3]. Not only education, COVID-19 a ffects many aspects of human life in all a spects like business, research, health, economy, sports, trans portation, worship, social interaction, politics, government, and entertainment [4]. This pandemic has directly affected higher education and the student experience[5]. There are many ways to deal with the spread of Covid-19virus, one of them is the existence of Large-Scale Social Restrictions or PSBB[6]. In the field of education, new learning models must be a pplied to overcome these problems, one of them is the online learning model. The presence of the internet has encouraged developers to give new innovations a nd we now live in a world that is increa singly dependent on the use of internet information technology [7]. Various applications were created to meet the needs of human socialization[8]. Knowledge of ethics in cyberspace (netiquette) must be owned by people who spend a lot of time in cyberspace[9]. It creates a new problem for students and lecturers, where ethics in communication becomes a problem during theonline learning process. Thus, the concept of netiquette becomes important in online learning during the pandemic [10]. 
Lack of knowledge in ethics which is not written in the internet for the use of email, chat, and mailing lists can bring its users to an unhealthy situation if the users donot understand the culture on the Internet[11]. In that case, the application is one of the most commonly used applications [12], [13]. Therefore, it is important to implement the concept of netiquette to the students in communicating and conducting social interactions. In Indonesia, netiquette is known a s internet etiquette by internet users (netters). Politeness a nd communication that must be owned by students. So that they are able to support the develo pment of social competencies owned by the students.

There are 9 assessment criteria used which are rela ted to the concept of Netiquette. When decision makers are faced with a problem, there are several predetermined a lternatives such as the M ADM method with the context of selecting the problem, sorting the problem, ra nking and describing the problem. TOPSIS is very suitable for the problem[14]. In practical decision problems, TOPSIS is very suitable for the problem[14] because TOPSIS offers a set of tools and it provides a $\mathrm{n}$ a ssessment of the student's social competence. This method was chosen because it is able to choose the best alternative from several ex isting alternatives based on specified criteria [15]-[17]. Using this method, you will be able to rank from a number of a lternative choices[18]. The results of this study may change, a cording to the weighting of the criteria. It is because users have different assessments of interest in the criteria used. There a re many studies that discuss netiquette, but this study can provide an assessment of the priority scale of the weights a gain st the criteria used and perform a rank to conduct a screening of students' soft skills for the needs of the world of work.

\section{RESEARCHMETHOD}

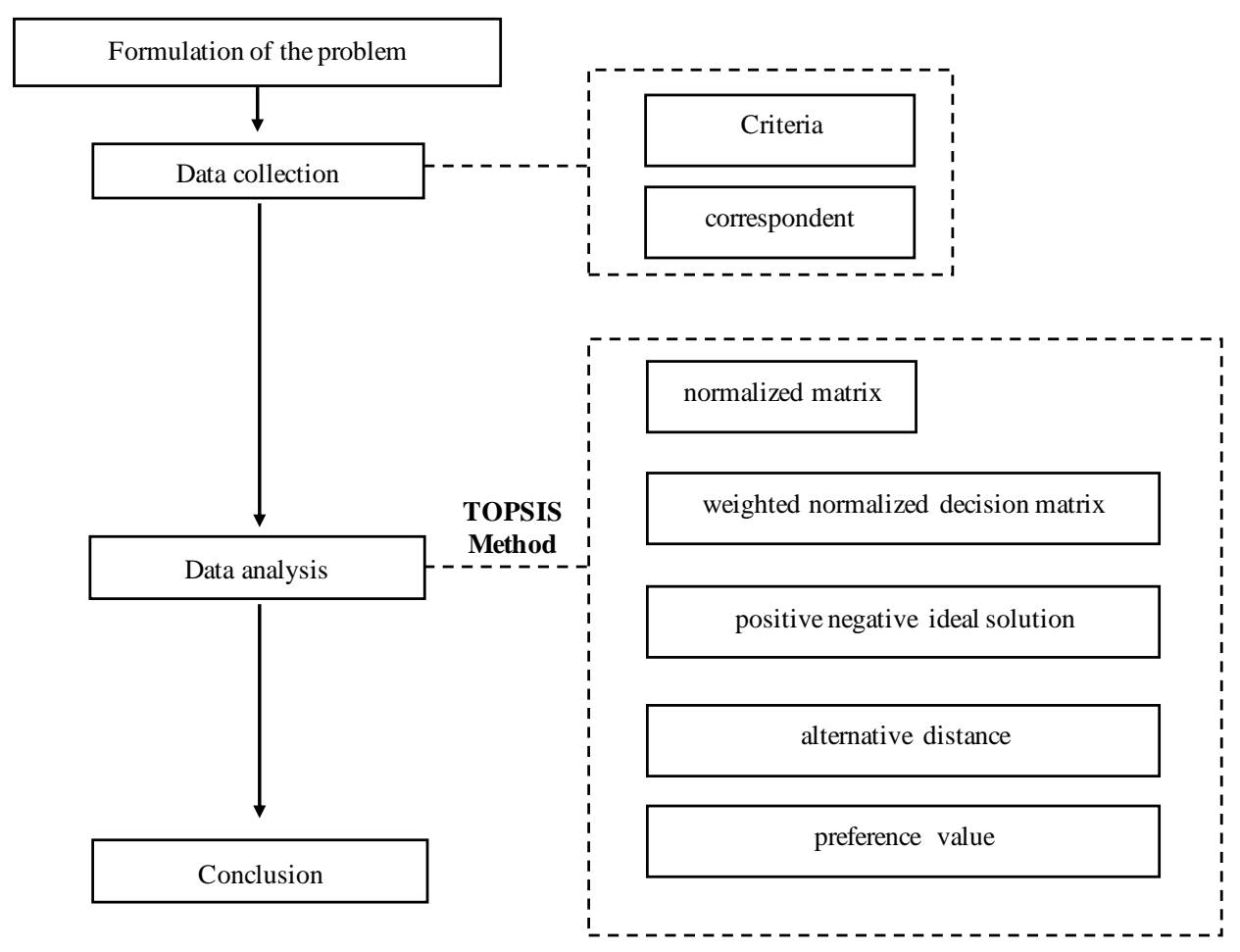

Figure 1. Research flow

This stage begins from formulation of the problem and then data collection, which is obtained from literature studies and field studies. Literature studies were ta ken from the journal litera ture and field st udies. In literature, TOPSIS method is very suitable in making decisions that involve criteria to get quick and objective results. While field studies were carried out with discussions from the participants [18]. The data obta ined were grouped based on needs and data analysis was carried out to obtain an appropriate model for this research that will be used for the social competence of practicum students. In this a ssessment of social competence using the TOPSIS method, the TOPSIS method used the principle that the chosen alternative must have the shortest distance from the positive ideal solution and the farthest from the negative ideal solution. It wa s used to determine the relative proximity of an alternative[19]. 
Using the TOPSIS method, there were several steps that must be done. First is normalized decision matrix. Normalized matrix was obtained by dividing each value of the criteria divided by the number of matrixes in each column. The normalized matrix can be done using the following equation:

$$
r j=\frac{x_{i j}}{\sqrt{\sum_{i=1}^{m} x_{i j}}}
$$

Weighted normalized determined the weighted normalized decision matrix. It was obtained by multiplying the weight with the va lue of each a ttribute calculated by the following equation:

$$
\left[\begin{array}{ccc}
W_{1} r_{11} & W_{2} v_{12} & W_{n} r_{n} \\
W_{1} r_{21} & \cdots & m \\
W_{j} v_{1 m} & W_{j} v_{2 m} & W_{j} v_{m m}
\end{array}\right]
$$

Next is determine the value of the positive ideal solution a nd the negative ideal solution. The ideal solution is called $\mathrm{A}+$, while the negative ideal solution is called $\mathrm{A}-$. To find the value of the positive ideal solution and the value of the negative ideal solution can be seen in the following equation:

$$
\begin{aligned}
& A+=\left\{\max \left(h_{i j} \mid i \in I^{*}\right), \min \left(h_{i j} \mid i \in I^{*}\right), j=1,2, \ldots, m\right\}=\left\{h_{1}^{+}, h_{2, \ldots}^{+}, h_{m}^{+}\right\} \\
& A-=\left\{\min \left(h_{i j} \mid i \in I^{*}\right), \max \left(h_{i j} \mid i \in I^{*}\right), j=1,2, \ldots, m\right\}=\left\{h_{1}^{-}, h_{2}^{-}, \ldots, h_{m}^{-}\right\}
\end{aligned}
$$

Next is calculate the value of the separation measure. It was done by measuring the distance fro $\mathrm{m}$ the alternative to the positive ideal solution and the negative ideal solution. The measurement of the alternative distance of the positive ideal solution is symbolized by $\mathrm{D}+$ and the dist ance of the a lternative negative ideal solution is symbolized by D-, the equation to find the value is a s follows:

$$
\begin{aligned}
& D+=\sqrt{\sum_{j-=1}^{m} W_{j}^{2}\left(h_{i j}-h_{j}^{+}\right), i=1,2_{v \ldots}} \\
& D-=\sqrt{\sum_{j-=1}^{m} W_{j}^{2}\left(h_{i j}-h_{j}^{-}\right), i=1,2_{v \ldots}}
\end{aligned}
$$

Next is determine the preference value for each alternative where the preference value is the proximity of the alternative to theideal solution. The value of the preference for the alternative is symbolized by $\mathrm{Ci}$, which can be calculated by the following equation:

$$
C_{i}=\frac{D_{\bar{i}}}{D_{i}+D_{\bar{i}}} 0 \leq C_{i} \leq 1,1=1,2, \ldots m
$$

From the value obtained from the preference value, a rank is obtained for each student.

This a ssessment uses nine criteria which can be seen in table 1 . The use of criteria is ba sed on the concept of netiquette when communicating in cyberspace[20].

Table 1. Netiquette Concept Assessment Criteria

\begin{tabular}{llcc}
\hline & \multicolumn{1}{c}{ Criterion } & Benefit/Cost & $\begin{array}{c}\text { weight of } \\
\text { criterion }\end{array}$ \\
\hline K1 & $\begin{array}{l}\text { Ability to collaborate for the benefit of learning during the practicum } \\
\text { process }\end{array}$ & Benefit & 0,74 \\
K2 & Able to resolve social conflicts in practicum group units & Benefit & 0,96 \\
K3 & Able to interact well with all colleagues in the practicum environment & Benefit & 1,22 \\
K4 & Selfless and respect other people's talk & Benefit & 1,09 \\
K5 & Dare to give advice without going beyond the boundaries of politeness & Benefit & 1,25 \\
K6 & Care about the conditions in the surrounding environment during the & Benefit & 1,45 \\
& practicum & Cost & 1,23 \\
K7 & Speak at will, without paying attention to others & Benefit & 0,89 \\
K8 & Communicate properly and correctly & Benefit & 1,17 \\
K9 & Always respect and respect the interlocutor & & \\
\hline
\end{tabular}

Using the criteria showed in table 1, the scores was obtained from the distribution of questionnaire s to students at the practicum, which were distributed by peers. The results showed that with a range of $1-5$, 
the criteria "very" $=5$; "often done" $=4$; "sometimes done" $=3$; "rarely done" $=2$; "never do ne" $=1$. The weighting of the criteria values was given by the practicum supervisor by paying attention to theconcept of netiquette when carrying out the weighing process.

\section{RESULTS AND ANALYSIS}

TOPSIS is an efficient MCDM methodology, it was first introduced by Hwang and Yoon[17] to determine the best option based on the best solution. The next stage is the selection of alternatives by choosing the right alternative using the TOPSIS algorithm[21]. The first stage of using the TOPSIS m ethod wa s to create a pairwise comparison matrix. At this sta ge, the value of each u ser's criteria was compared with other users, then a dded up the column values of each criterion.

Table 2. Pairwise Comparison Matrix

\begin{tabular}{cccccccccc}
\hline Students & K1 & K2 & K3 & K4 & K5 & K6 & K7 & K8 & K9 \\
\hline M01 & 4 & 4 & 5 & 5 & 5 & 5 & 3 & 4 & 4 \\
M02 & 3 & 4 & 3 & 4 & 1 & 4 & 2 & 4 & 4 \\
M03 & 4 & 4 & 4 & 4 & 4 & 4 & 2 & 4 & 4 \\
M04 & 5 & 5 & 5 & 5 & 5 & 5 & 2 & 4 & 5 \\
M05 & 4 & 5 & 5 & 4 & 4 & 4 & 2 & 5 & 5 \\
M06 & 4 & 4 & 5 & 5 & 5 & 4 & 2 & 5 & 5 \\
M07 & 3 & 4 & 5 & 5 & 4 & 5 & 4 & 4 & 5 \\
M08 & 4 & 4 & 4 & 4 & 4 & 4 & 1 & 5 & 4 \\
M09 & 1 & 2 & 4 & 3 & 3 & 3 & 3 & 3 & 3 \\
M10 & 4 & 4 & 4 & 4 & 5 & 5 & 1 & 4 & 4 \\
$\ldots$ & $\ldots$ & $\ldots$ & $\ldots$ & $\ldots$ & $\ldots$ & $\ldots$ & $\ldots$ & $\ldots$ & $\ldots$ \\
M70 & 4 & 5 & 5 & 4 & 5 & 5 & 2 & 5 & 5 \\
M71 & 4 & 5 & 3 & 4 & 4 & 4 & 2 & 3 & 4 \\
M72 & 5 & 5 & 5 & 5 & 5 & 5 & 5 & 5 & 5 \\
M73 & 3 & 4 & 4 & 4 & 4 & 4 & 3 & 4 & 5 \\
M74 & 2 & 3 & 3 & 3 & 3 & 3 & 3 & 3 & 3 \\
M75 & 3 & 3 & 4 & 3 & 3 & 4 & 2 & 4 & 3 \\
M76 & 3 & 5 & 5 & 4 & 5 & 4 & 3 & 4 & 5 \\
M77 & 3 & 5 & 5 & 4 & 5 & 4 & 3 & 4 & 5 \\
M78 & 4 & 3 & 4 & 5 & 4 & 4 & 2 & 4 & 5 \\
\hline
\end{tabular}

Table 2 is a pairwise comparison matrix, where the value was obtained from the value of each criterion for each alternative choice. By adding up each column of the matrix, the total value of each colu mn of criteria was obtained where the value will be used for the matrix normalization stage. At the matrix normalization stage, it can use equation (1), where the results of the matrix normalization can be seen in table 3.

Table 3. Matrix Normalization

\begin{tabular}{|c|c|c|c|c|c|c|c|c|c|}
\hline Students & K1 & $\mathrm{K} 2$ & K3 & K4 & K5 & K6 & K7 & K8 & K9 \\
\hline M01 & 0,0149 & 0,0125 & 0,0156 & 0,0157 & 0,0166 & 0,0161 & 0,0192 & 0,0125 & 0,0123 \\
\hline M02 & 0,0112 & 0,0125 & 0,0093 & 0,0125 & 0,0033 & 0,0129 & 0,0128 & 0,0125 & 0,0123 \\
\hline M03 & 0,0149 & 0,0125 & 0,0125 & 0,0125 & 0,0133 & 0,0129 & 0,0128 & 0,0125 & 0,0123 \\
\hline M04 & 0,0187 & 0,0156 & 0,0156 & 0,0157 & 0,0166 & 0,0161 & 0,0128 & 0,0125 & 0,0154 \\
\hline M05 & 0,0149 & 0,0156 & 0,0156 & 0,0125 & 0,0133 & 0,0129 & 0,0128 & 0,0156 & 0,0154 \\
\hline M06 & 0,0149 & 0,0125 & 0,0156 & 0,0157 & 0,0166 & 0,0129 & 0,0128 & 0,0156 & 0,0154 \\
\hline M07 & 0,0112 & 0,0125 & 0,0156 & 0,0157 & 0,0133 & 0,0161 & 0,0256 & 0,0125 & 0,0154 \\
\hline M08 & 0,0149 & 0,0125 & 0,0125 & 0,0125 & 0,0133 & 0,0129 & 0,0064 & 0,0156 & 0,0123 \\
\hline M09 & 0,0037 & 0,0063 & 0,0125 & 0,0094 & 0,0100 & 0,0097 & 0,0192 & 0,0093 & 0,0093 \\
\hline M10 & 0,0149 & 0,0125 & 0,0125 & 0,0125 & 0,0166 & 0,0161 & 0,0064 & 0,0125 & 0,0123 \\
\hline$\ldots$ & $\ldots$. & $\ldots$. & $\cdots$ & $\cdots$ & & & & & \\
\hline M70 & 0,0149 & 0,0156 & 0,0156 & 0,0125 & 0,0166 & 0,0161 & 0,0128 & 0,0156 & 0,0154 \\
\hline M71 & 0,0149 & 0,0156 & 0,0093 & 0,0125 & 0,0133 & 0,0129 & 0,0128 & 0,0093 & 0,0123 \\
\hline M72 & 0,0187 & 0,0156 & 0,0156 & 0,0157 & 0,0166 & 0,0161 & 0,0321 & 0,0156 & 0,0154 \\
\hline M73 & 0,0112 & 0,0125 & 0,0125 & 0,0125 & 0,0133 & 0,0129 & 0,0192 & 0,0125 & 0,0154 \\
\hline M74 & 0,0075 & 0,0094 & 0,0093 & 0,0094 & 0,0100 & 0,0097 & 0,0192 & 0,0093 & 0,0093 \\
\hline M75 & 0,0112 & 0,0094 & 0,0125 & 0,0094 & 0,0100 & 0,0129 & 0,0128 & 0,0125 & 0,0093 \\
\hline M76 & 0,0112 & 0,0156 & 0,0156 & 0,0125 & 0,0166 & 0,0129 & 0,0192 & 0,0125 & 0,0154 \\
\hline M77 & 0,0112 & 0,0156 & 0,0156 & 0,0125 & 0,0166 & 0,0129 & 0,0192 & 0,0125 & 0,0154 \\
\hline M78 & 0,0149 & 0,0094 & 0,0125 & 0,0157 & 0,0133 & 0,0129 & 0,0128 & 0,0125 & 0,0154 \\
\hline
\end{tabular}


The results of the normalization of the matrix in table 3 can be calculated from the value of the weight of the normalized decision matrix using equation (2). The weighted normalization matrix was calculated by multiplying the weight of each criterion by the value of each column of the normalized matrix . The results of the calculation of the weighted normalization matrix can be seen in table 4 .

Table 4. Weighted Matrix Normalization

\begin{tabular}{ccccccccccc}
\hline Students & K1 & K2 & K3 & K4 & K5 & K6 & K7 & K8 & K9 \\
& 0,74 & 0,96 & 1,22 & 1,09 & 1,25 & 1,45 & 1,23 & 0,89 & 1,17 \\
\hline M01 & 0,0110 & 0,0120 & 0,0190 & 0,0171 & 0,0208 & 0,0234 & 0,0237 & 0,0111 & 0,0144 \\
M02 & 0,0083 & 0,0120 & 0,0114 & 0,0137 & 0,0042 & 0,0187 & 0,0158 & 0,0111 & 0,0144 \\
M03 & 0,0110 & 0,0120 & 0,0152 & 0,0137 & 0,0166 & 0,0187 & 0,0158 & 0,0111 & 0,0144 \\
M04 & 0,0138 & 0,0150 & 0,0190 & 0,0171 & 0,0208 & 0,0234 & 0,0158 & 0,0111 & 0,0181 \\
M05 & 0,0110 & 0,0150 & 0,0190 & 0,0137 & 0,0166 & 0,0187 & 0,0158 & 0,0139 & 0,0181 \\
M06 & 0,0110 & 0,0120 & 0,0190 & 0,0171 & 0,0208 & 0,0187 & 0,0158 & 0,0139 & 0,0181 \\
M07 & 0,0083 & 0,0120 & 0,0190 & 0,0171 & 0,0166 & 0,0234 & 0,0315 & 0,0111 & 0,0181 \\
M08 & 0,0110 & 0,0120 & 0,0152 & 0,0137 & 0,0166 & 0,0187 & 0,0079 & 0,0139 & 0,0144 \\
M09 & 0,0028 & 0,0060 & 0,0152 & 0,0103 & 0,0125 & 0,0140 & 0,0237 & 0,0083 & 0,0108 \\
M10 & 0,0110 & 0,0120 & 0,0152 & 0,0137 & 0,0208 & 0,0234 & 0,0079 & 0,0111 & 0,0144 \\
‥ & $\ldots$ & $\ldots$. & $\ldots \ldots$ & $\ldots$ & $\ldots$ & $\ldots$ & $\ldots$ & $\ldots$ \\
M70 & 0,0110 & 0,0150 & 0,0190 & 0,0137 & 0,0208 & 0,0234 & 0,0158 & 0,0139 & 0,0181 \\
M71 & 0,0110 & 0,0150 & 0,0114 & 0,0137 & 0,0166 & 0,0187 & 0,0158 & 0,0083 & 0,0144 \\
M72 & 0,0138 & 0,0150 & 0,0190 & 0,0171 & 0,0208 & 0,0234 & 0,0394 & 0,0139 & 0,0181 \\
M73 & 0,0083 & 0,0120 & 0,0152 & 0,0137 & 0,0166 & 0,0187 & 0,0237 & 0,0111 & 0,0181 \\
M74 & 0,0055 & 0,0090 & 0,0114 & 0,0103 & 0,0125 & 0,0140 & 0,0237 & 0,0083 & 0,0108 \\
M75 & 0,0083 & 0,0090 & 0,0152 & 0,0103 & 0,0125 & 0,0187 & 0,0158 & 0,0111 & 0,0108 \\
M76 & 0,0083 & 0,0150 & 0,0190 & 0,0137 & 0,0208 & 0,0187 & 0,0237 & 0,0111 & 0,0181 \\
M77 & 0,0083 & 0,0150 & 0,0190 & 0,0137 & 0,0208 & 0,0187 & 0,0237 & 0,0111 & 0,0181 \\
M78 & 0,0110 & 0,0090 & 0,0152 & 0,0171 & 0,0166 & 0,0187 & 0,0158 & 0,0111 & 0,0181 \\
\hline
\end{tabular}

Based on the values obtained in table 4, the next step wa s tofind the value of the positive ideal solution and the negativeideal solution. The value of the positive ideal solution was taken from the la rgest value from each column of alternative choices if the criteria were benefit and the smallest value wa s taken from each column of alternative choices if the criteria were cost. While the value of the negative ideal solution was taken from the smallest value of each alternative column of choice if the criteria we re ben efit and the la rgest value was taken from each column of alternative choices if the criteria were cost. The results of the values of positive ideal solutions and negative ideal solutions can be seen in table 5 .

Table 5. Positive and Negative Ideal Solutions

\begin{tabular}{cccccccccc}
\hline $\mathrm{A}+$ & 0,01381 & 0,01500 & 0,01900 & 0,01708 & 0,02076 & 0,02339 & 0,00788 & 0,01386 & 0,01806 \\
$\mathrm{~A}-$ & 0,00276 & 0,00300 & 0,00380 & 0,00342 & 0,00415 & 0,00468 & 0,03942 & 0,00277 & 0,00361 \\
\hline
\end{tabular}

After obtaining the value of the positive ideal solution and the negative ideal solution, the next step was to calculate the value of the separation measure. The separation measure was the distance from a $n$ alternative to a positive ideal solu tion and a negativeideal solution. Calculations to find the value of the sepa ration measure can u se equations (5) and (6). The results of the calculation of the value of the separation measure can be seen in table 6 .

Table 6. Separation Measure

\begin{tabular}{ccc}
\hline Students & D+ & D- \\
\hline M01 & 0,05280 & 0,05280 \\
M02 & 0,03843 & 0,03843 \\
M03 & 0,04348 & 0,04348 \\
M04 & 0,05239 & 0,05239 \\
M05 & 0,04783 & 0,04783 \\
M06 & 0,04967 & 0,04967 \\
M07 & 0,05597 & 0,05597 \\
M08 & 0,04211 & 0,04211 \\
M09 & 0,03844 & 0,03844 \\
M10 & 0,04534 & 0,04534 \\
.. & $\ldots$ & $\ldots$ \\
M70 & 0,05138 & 0,05138 \\
M71 & 0,04262 & 0,04262 \\
M72 & 0,06418 & 0,06418
\end{tabular}




\begin{tabular}{lll} 
M73 & 0,04759 & 0,04759 \\
M74 & 0,03801 & 0,03801 \\
M75 & 0,03847 & 0,03847 \\
M76 & 0,05130 & 0,05130 \\
M77 & 0,05130 & 0,05130 \\
M78 & 0,04527 & 0,04527 \\
\hline
\end{tabular}

After the separation measure value was known, the next step was to find the preference value whic $h$ was the alternative closeness to theideal solution. To calculate the value of the relative coefficient can use equation (7). After the value of the rela tive coefficient was obtained, the next step was to determine the be st rank of students who had an assessment of social competence. The overall value of the above calculations can be seen in table 7.

Table 7. The Choice Alternative Ranking

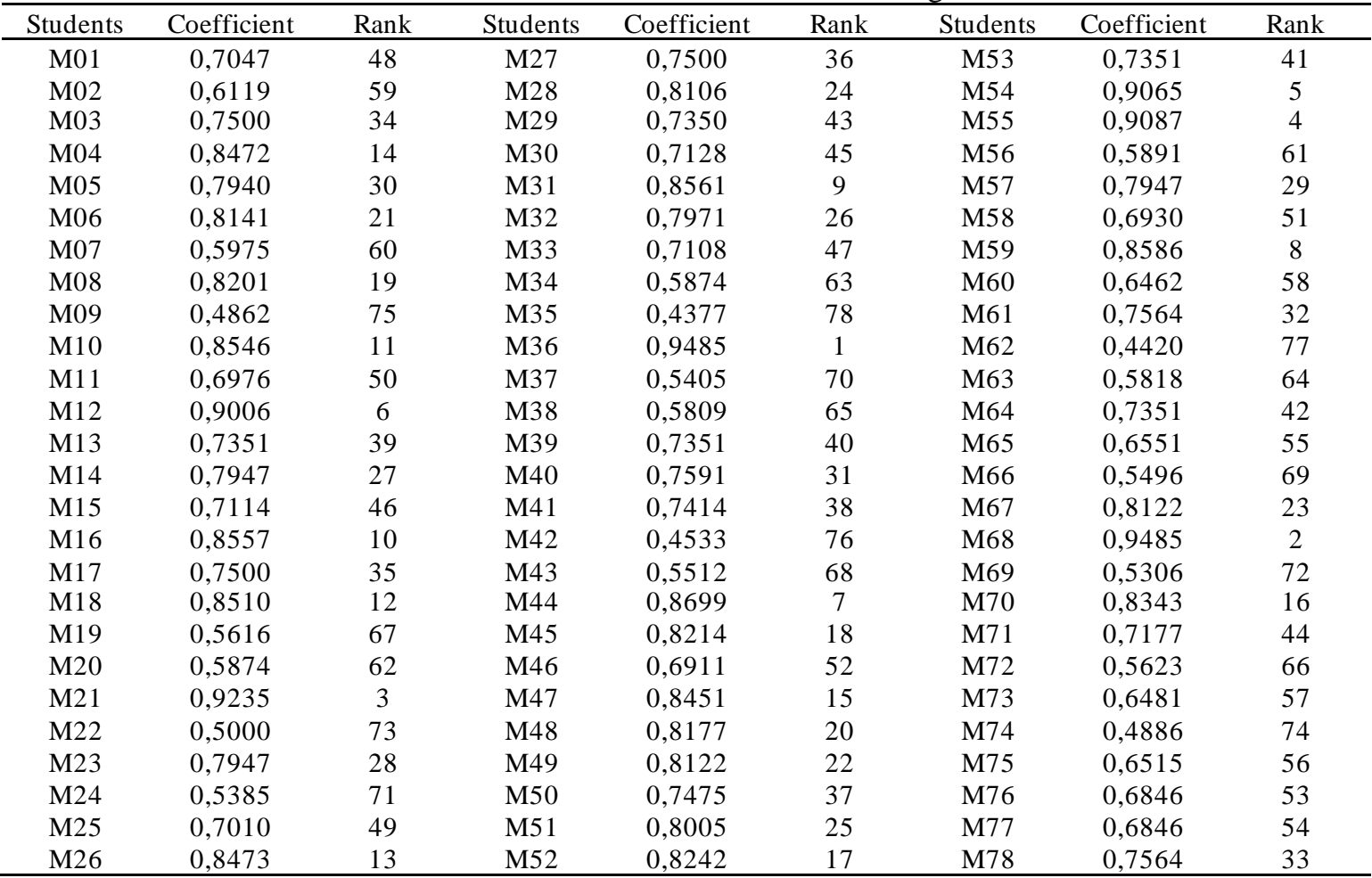

Table 7 was a nalternativechoice of 78 students who did the practicum. In the table, the highest score is 0.9485 by M36 practicum students, while the lowest score is 0.4377 by M35 students. Based on table 7 , the practicum supervisor can assess the personality of each student regarding the student's social competence, by taking the value from the best. Ba sed on this rank, it shows that students have the potential to rea lize the Adisutjipto Institute of Aerospace Technology in graduating alumni with globaland human istic characters. It is because, except the hard skills, soft skills are a supporting factor.

\section{CONCLUSION}

This study can provide a n assessment of the social competence of practicum students. In addition to hard skills, students must also have soft skills that come from socialcompetence. It is because they a re indirectly used in everyday life, especially in the world of work. Determination of criteria a nd weighting of criteria are very important in the use of this method, because it will affect the results to be obtained. The u se of this method has shortcomings in the va lidation process in assigning weighting crite ria. In a ddition, the mea surement of the real results cannot be known in the short term a bout the accuracy of the results from the use of this method. Therefore, complementary methods a re needed, which can support further research. 


\section{REFERENCES}

[1] W. Tan et al., "A Novel Coronavirus Genome Identified in a Cluster of Pneumonia Cases - Wuhan, China 20192020.," China CDC Wkly., vol. 2, no. 4, pp. 61-62, 2020.

[2] S. Van de Velde et al., "Depressive symptoms in higher education students during the first wave of the COVID19 pandemic. An examination of the association with various social risk factors across multiple high- and middle-income countries," SSM - Popul. Heal., vol. 16, no. June, p. 100936, 2021.

[3] T. Hale, A. Noam, K. Beatriz, A. Petherick, T. Phillips, and S. Webster, "Variations in government responses to COVID-19 Version 7.0," Blavatnik Sch. Gov. Work. Pap., vol. 31, pp. 2011-2020, 2020.

[4] S. N. Orfan and A. H. Elmyar, "Public Knowledge, Practices and Attitudes Towards Covid-19 in Afghanistan," Public Heal. Indones. , vol. 6, no. 4, pp. 104-115, 2020.

[5] D. Mali and H. Lim, "How do students perceive face-to-face/blended learning as a result of the Covid-19 pandemic?,"Int. J. Manag. Educ., vol. 19, no. 3, p. 100552, 2021.

[6] N. Mona, "Konsep Isolasi Dalam Jaringan Sosial Untuk Meminimalisasi Efek Contagious (Kasus Penyebaran Virus Corona Di Indonesia)," J. Sos. Hum. Terap., vol. 2, no. 2, pp. 117-125, 2020.

[7] R. Khani and R. Darabi, "Flouting the Netiquette Rules in the Academic Correspondence in Ir an," Procedia Soc. Behav. Sci., vol. 98, pp. 898-907, 2014.

[8] Y. Fahrimal, "Netiquette: Etika Jejaring Sosial Generasi Milenial Dalam Media Sosial," J. Penelit. Pers dan Komun. Pembang., vol. 22, no. 1, pp. 69-78, 2018.

[9] Y. S. Sitepu, "Persepsi Mahasiswa Fisip Universitas Sumatera Utara Mengenai Netiket Di Dunia Maya," Sociae Polites, vol. 15, no. 1, pp. 85-104, 2017.

[10] E. Moradi and F. Amirpoursaeed, "Netiquette and its application in virtual learning: a vital necessity in medical universities during the COVID-19," J. Med. Educ. Dev., vol. 16, no. 2, 2021.

[11] Y. Fahrimal, "Etika Berkomunikasi di Dunia Maya dengan Netiquette," Semin. Nas. Mat. dan Pendidik. Mat., vol. 22, no. 1, pp. 69-78, 2006.

[12] V. Ho, "Constructing identities through request e-mail discourse," J. Pragmat., vol. 42, no. 8, pp. 2253-2261, 2010.

[13] J. M. Lightfoot, "A comparative analysis of e-mail and face-to-face communication in an educational environment," Internet High. Educ., vol. 9, no. 3, pp. 217-227, 2006.

[14] B. Roy, "The Optimisation Problem Formulation: Criticism and Overstepping," J. Oper. Res. Soc., vol. 32, no. 6, pp. 427-436, 1981.

[15] A. Borawska, "Multiple-Criteria Decision Analysis Using Topsis Method For Interval Data In Research Into The Level Of Information Society Development," Folia Oeconomica Stetin., vol. 13, 2014.

[16] G. Kabir and A. A. Hasin, "COMPARATIVE ANALYSIS OF TOPSIS AND FUZZY TOPSIS FOR THE EVALUATION OF TRAVEL WEBSITE SERVICE QUALITY," 2012.

[17] S. H. Zanakis, A. Solomon, N. A. Wishart, and S. Dublish, "Multi-attribute decision making: A simulation comparison of select methods," Eur. J. Oper. Res., vol. 107, pp. 507-529, 1998.

[18] R. Rahim et al., "TOPSIS Method Application for Decision Support System in Internal Control for Selecting Best Employees," J. Phys. Conf. Ser., vol. 1028, no. 1, pp. 1-8, 2018.

[19] A. M. Yaakob and A. Gegov, "Interactive TOPSIS Based Group Decision Making Methodology UsingZNumbers," Int. J. Comput. Intell. Syst., vol. 9, no. 2, pp. 311-324, 2016.

[20] R. Soler-Costa, P. Lafarga-Ostáriz, M. Mauri-Medrano, and A. J. Moreno-Guerrero, "Netiquette: Ethic, education, and behavior on internet—a systematic literature review," Int. J. Environ. Res. Public Health, vol. 18, no. 3, pp. 1-15, 2021.

[21] B. Singaravel and T. Selvaraj, "Optimizacija parametara obrade u postupcima tokarenja primjenom kombinacije TOPSIS i AHP metode,” Teh. Vjesn., vol. 22, no. 6, pp. 1475-1480, 2015. 
